University of Pennsylvania Carey Law School

Penn Law: Legal Scholarship Repository

Faculty Scholarship at Penn Law

2021

\title{
Built on Borders? Tensions with the Institution Liberalism (Thought It) Left Behind
}

\author{
Beth A. Simmons \\ University of Pennsylvania Carey Law School \\ Hein E. Goemans \\ University of Rochester
}

Follow this and additional works at: https://scholarship.law.upenn.edu/faculty_scholarship

Part of the Immigration Law Commons, International Law Commons, International Relations Commons, Law and Politics Commons, and the Political Theory Commons

\section{Repository Citation}

Simmons, Beth A. and Goemans, Hein E., "Built on Borders? Tensions with the Institution Liberalism (Thought It) Left Behind" (2021). Faculty Scholarship at Penn Law. 2460.

https://scholarship.law.upenn.edu/faculty_scholarship/2460

This Article is brought to you for free and open access by Penn Law: Legal Scholarship Repository. It has been accepted for inclusion in Faculty Scholarship at Penn Law by an authorized administrator of Penn Law: Legal Scholarship Repository. For more information, please contact PennlawIR@law.upenn.edu. 
[PUBLISHED IN INTERNATIONAL ORGANIZATION, 75:2, 387 - 410, 2021]

\title{
Built on Borders: Tensions with the Institution Liberalism (Thought It) Left Behind
}

\author{
Beth A. Simmons \\ Andrea Mitchell University Professor of Law, Political Science and Business Ethics \\ University of Pennsylvania \\ simmons3@law.upenn.edu
}

Hein E. Goemans

Professor of Political Science

Director of the Peter D. Watson Center for Conflict and Cooperation

University of Rochester

henk.goemans@rochester.edu

Received October 5, 2019; Accepted October 8, 2020

\begin{abstract}
The Liberal International Order is in crisis. While the symptoms are clear to many, the deep roots of this crisis remain obscured. We propose that the Liberal International Order is in tension with the older Sovereign Territorial Order, which is founded on territoriality and borders to create group identities, the territorial state, and the modern international system. The Liberal International Order, in contrast, privileges universality at the expense of groups and group rights. A recognition of this fundamental tension makes it possible to see that some crises that were thought to be unconnected have a common cause: the neglect of the coordinating power of borders. We sketch out new research agendas to show how this tension manifests itself in a broad range of phenomena of interest.
\end{abstract}

Acknowledgments: We thank the editors of International Organization and the participants at the 75th-anniversary conferences in Madison, Wisconsin, and Berlin, Germany. We also thank Jordan Branch, Karen Goldfeder, Christopher Herbert, Michiel Kleiss, Daniel Nexon, Anne Norton, Kenneth Schultz, and John Tasioulas for sources, discussion, and comments. 


\section{Introduction}

Liberal internationalism emphasizes values such as integrated markets, universal rights, and aggregate welfare. Human attachments tend to be local, discriminating, and spatial. Much research in the pages of International Organization $(I O)$ has been devoted to the former, to the relative neglect of the latter. Liberalism tends to elide borders and challenge identities (and privileges) tied to place. These elisions have created new tensions around liminal space, political authority, in-group privilege, and ultimately group identity itself. Borders at all levels - around communities, towns, provinces, and states - have historically facilitated group identities and coordinated social functions. When accepted borders begin to dissolve, new social distinctions emerge, and dominant groups reassert border security and localized control. We argue that these dynamics help account for the increase in border politics visible in many parts of the world today.

The red thread in our essay is the observation that the Liberal International Order (LIO) and scholarship in $I O$ may have underestimated the spatial foundations of contemporary identity and political authority. The LIO functions like an addition built onto an eighteenth-century house, the foundations of which are firmly rooted in spatialized, territorial identities and authority. These foundations constrain and sometimes even subvert the purported values of the LIO, from universal human rights to market integration. Territorial authority uses borders to help create and reinforce groups, identities, and privileges. It provides the foundation for modern state sovereignty. In this sense, international borders are encoded into the DNA of the modern state system. Yet liberal theory has relatively little to say about legitimacy rooted in delimited space. We suggest that spatial perspectives — our block, our neighborhood, our country — fundamentally affect preferences and behavior. Modern border politics play on these perceptions. States use international borders as political reinforcements to maintain the power and legitimacy of the state. Our reconsideration of space and place suggests a research agenda that investigates the contradictions between the LIO and perceived threats to national and local notions of security. Such an agenda is likely to reveal pressure to resurrect and reify interstate borders where accelerated changes due to globalization have challenged them, and by extension, the state itself. 
In Section II we sketch the foundations of what we call the Sovereign Territorial Order (STO), by which we mean the international order where the primary actors are territorial states, ${ }^{1}$ and the political and economic dynamics it reflects. We then turn to the fundamentals of the post-1945 LIO. It is tempting to conclude that the two orders have coevolved. To be sure, through interaction each has fundamentally influenced the development of the other in ways that cannot easily be reversed. For example, the LIO has never been very liberal for migrants, and territorial states have conceded some minimal limits on their authority to abuse the human rights of their own people within their own borders. However, the fundamental and contradictory logics and principles of these orders remain essentially intact and in tension. Political actors with vested interests in these respective orders have negotiated international concession-making on a piecemeal basis since the end of the Second World War; "embedded liberalism"2 was one such compromise. However, the fundamental principles of the two opposing orders have not been reconciled.

We build on the observation that, despite the many attractions of liberal principles, in the modern world bordering is fundamental to identity formation and collective action. In Section III we argue that the "de-bordering" values of the LIO have led to (1) shifting and exclusionary social identity reactions, (2) erosion of state legitimacy through a diffusion of responsibilities and weakened accountability; and (3) re-bordering, a renewed emphasis on border control. In Section IV we propose a research agenda to investigate the resurgence of identities rooted in bounded space and their resistance to the hyperglobalization of the 1990s. We call for research that analyzes the LIO while more fully accounting for spatialized local preferences.

\section{The Two Orders}

\footnotetext{
${ }^{1}$ We reject the term "Westphalian Order" because this label gets the date, causality, and (cartographic) structure of the current system wrong. The term typically refers to an international order that no longer relied on the fiction of two competing hierarchies of power: the one secular, with the Holy Roman Emperor at the apex; the other religious, with the Pope at its apex. Instead, these hierarchies of power were now formally and effectively declared to be superseded by a system of nominally equal and independent actors. Recent scholarship has rejected the Peace of Westphalia as a decisive break in its own right (Osiander 2001). The transition was much more gradual. We disagree with the reference to a Westphalian Order as characterizing the international system of the last two centuries, because the Peace of Westphalia predates the effects of the cartographic revolution and the usage of maps and bordering by at least two centuries (Branch 2011).

${ }^{2}$ Ruggie 1982.
} 


\section{Bounded Territoriality: The Roots of the STO}

Any intergroup order must be defined by rules of group membership and rules of political authority. Territorial states are the central actors in international relations (IR). But IR scholars have not fully grasped the reasons for and consequences of the dominance of territorial states. The connection between place, identity, and political authority is evident throughout recorded history. Renaissance ideas fundamentally challenged these connections by separating the state from the person of the monarch, claims of authority from kinship, and dynastic rule from religious justification. ${ }^{3}$ During the eighteenth and nineteenth centuries the cartographic revolution - the rediscovery of Ptolemy, cartography, and the graticule (the grid on the map) facilitated a new political order that combined place, space, identity, and political authority in powerful ways. In this new STO, claims to rule over and to belong to a group that were once based on principles of shared type were increasingly superseded and supplanted by claims based on the principle of exclusion by area. ${ }^{4}$ This process, facilitated by the rapidly spreading use of maps, took centuries to fully consolidate, and first reached its full expression in Europe in the last decades of the nineteenth century. Already by the beginning of the nineteenth century, however, "authority [in Europe] was understood exclusively as a delineated geometric expanse, depicted visually on maps." Colonial empires exported these processes, using cartography to establish their claims, delimit their holdings, and legitimize their rule in the unexplored lands of the New World, ${ }^{6}$ where the kinship and ethnic relations of the populations were unknown, and claims to direct dynastic succession were implausible. The imperialist strategy of territoriality was brutally imposed on local populations in the New World, but it proved attractive as imperialist rulers back in Europe agreed to use a common standard to delineate claims in the New World: longitude and latitude. Territoriality and linear boundaries were subsequently ensconced in Europe and then imposed in Asia and Africa, ${ }^{7}$ though with wide-ranging consequences for the entities that were eventually recognized as sovereign territorial states. ${ }^{8}$

The conceptual point is this: clear linear boundaries were attractive for emerging nation

\footnotetext{
${ }^{3}$ In Western Europe, religion was the dominant criterion for inclusion and exclusion from the community until the late seventeenth century (Rae 2002:7; see also Goettlich 2019; Maier 2016:75-76).

${ }^{4}$ Maier 2016:289. For the strategy of territoriality and its principle of exclusion by area, see Sack 1989 .

${ }^{5}$ Branch 2013:138.

${ }^{6}$ Branch 2013; Akerman 1995.

${ }^{7}$ Anderson 1991, Chap. 10.

${ }^{8}$ Jackson 1987.
} 
states because they helped define group membership. ${ }^{9}$ As Ostrom notes, "who is in and who is out of a defined set of relationships and thus with whom to cooperate" is the first essential principle for collective action. ${ }^{10}$ The project of defining group members is fundamental to the creation and reinforcement of group identities. ${ }^{11}$ Abbott argues that "social identities come into existence when social actors tie social boundaries together in certain ways. Boundaries come first, then entities." 12 Within those borders, rulers worked often violently to homogenize entire countries "from above." 13 By facilitating new spatial identities, the STO did more than demarcate spaces of political authority. It enabled new forms of collective identity and collective action. ${ }^{14}$ While these identities were by definition statewide in scope, they were not automatically "national" in content. The emphasis on common culture is but one potential statewide group identity. ${ }^{15}$ Two modern alternatives that come to mind are ideology and religion.

While it often involved violence, the strategy of territoriality was largely successful in the modern era. Maps combined with mass education to produce common knowledge of the standards of group membership. ${ }^{16}$ In this new era, individuals, whether citizens or rulers, could coordinate on a set of standards and norms to guide their behavior, and this coordination yielded increasing returns. Branch documents the power of coordination and standard-setting: "Even ... any map ... to resolve territorial conflicts, they feared that others would do so, hence making such maps important shapers of the conditions within which [territorial] negotiations would take place." ${ }^{17}$ Territorial delimitation, moreover, tended to empower central state rulers, since local

\footnotetext{
${ }^{9}$ Note that borders are not uniquely attractive: groups can be defined by type or area. Borders are focal, as in Schelling's understanding of that concept. We take no position on whether they are "innate."

${ }^{10}$ Ostrom 2000:149.

${ }^{11}$ Borders prompt people to consider themselves part of the same superordinate category, which produces border bias (Mishra and Mishra 2010:1582). Social Identity Theory, as developed by Tajfel and Turner (1979), offers a theory of group formation and its effects.

${ }^{12}$ Abbott 1995:860, emphasis added; see also Nail 2016.

${ }^{13}$ Gellner 1983. On the importance of institutions see Maier 2016:22; Grimson 2012; McNamee and Zhang 2019. On the deployment of infrastructure to reinforce political and cultural consolidation within national borders see Brenner 1998; Olsson and Hansson 2011.

${ }^{14}$ Balibar 2004:109 neatly summarizes the process as "the culmination of a construction of and by the state that identified the exercise of sovereign power with the reciprocal determination of territories, and thus with the attribution to the state of a right of eminent domain over populations and their movements, before making populations themselves the ultimate reference of the constitution of political powers in the framework of recognized territorial limits."

${ }^{15}$ But see Goemans 2006.

${ }^{16}$ Hardin 1995; Gellner 1983.

${ }^{17}$ Branch 2013:120.
} 
disputes would often be referred to them for resolution. ${ }^{18}$ In a rationalist formulation, defection from the strategy of territoriality will be costly. ${ }^{19}$ As a result, scholars in various fields argue that boundaries at all levels of scale "are implicated in reducing violence." ${ }^{20}$ This process had another important consequence: it supported identity formation around notional lines on the earth that created new bonds of belonging, while marginalizing groups who refused to submit to the power of European notions of territorial delimitation.

The STO brought together three distinct but intertwined phenomena: territorial governance, which overtook other claims to political authority by the eighteenth century; the practice of bordering, a tool to govern through exclusion by area, which helped consolidate the state; and identity formation, which was fundamentally shaped by borders. By the twentieth century, territorial sovereignty constituted a core norm of IR. ${ }^{21}$ Territorial integrity and international borders were institutionalized as the underlying, nonnegotiable bedrock of the international order from the days of the League of Nations, ${ }^{22}$ and reiterated with the formation of the United Nations. ${ }^{23}$ Bordered territoriality was so sacrosanct, in fact, that any debate over its central position barely rates a mention in the travaux préparatoires of the UN Charter. ${ }^{24}$

\section{The STO and the LIO: Diverging Theoretical Assumptions}

The LIO was a deliberate, if controversial, ${ }^{25}$ post-World War II effort to reorient the divisive nationalism of the first half of the twentieth century toward cooperation, commonality, and efficiency, even while enshrining territorial integrity as a bedrock principle. However, many of the LIO's central institutions at least partly diminished the salience of states' territorial borders (and thereby their effective authority). The United Nations and the European Coal and

\footnotetext{
18 Sahlins 1989.

${ }^{19}$ Compare Meyer et al. 1997. "World culture" is not especially well suited to explore the tensions between the LIO and the STO, which is our central concern.

${ }^{20}$ Brantingham et al. 2012:852.

${ }^{21}$ Zacher 2001; Barkin and Cronin 1994.

${ }^{22}$ Covenant of the League of Nations, Article 10.

${ }^{23}$ Charter of the United Nations, Article 2(4).

${ }^{24}$ El Ouali 2006:631-32 notes that territorial integrity was uncontroversial among states. Similarly, Gordon (1984) notes that the language of Article 2(4) of the Charter was widely accepted well before negotiations in San Francisco began.

25 These controversies have contemporary counterparts. The future of the liberal vision of international human rights is said to be fundamentally challenged by alternative values, authorities, and counter-mobilizations (Hopgood 2013). The desirability of rules governing trade are under challenge by the rise of BRICS and the decline of the traditional liberal trading powers (Hopewell 2016.) Zürn (2018) has written extensively about the legitimacy crisis of international institutions, from Europe to the WTO.
} 
Steel Agreement were explicitly designed to resolve potential problems between territorial states at an international level. The International Monetary Fund preserved each territorial state's right to issue currency and to develop national economic priorities, but was designed to stabilize the international monetary system, create obligations for macroeconomic adjustment, and pave the way for border-defying market forces. The International Trade Organization was meant to perforate national barriers to trade, coordinate their reduction, and integrate markets for goods and eventually for services, though it was rebuffed in its initial form and replaced by the General Agreement on Tariffs and Trade. The Universal Declaration of Human Rights was conceived as universal, and stipulated rights for all human beings, regardless of their location.

Tensions between the newly institutionalized LIO and the old STO are evident in early postwar debates. The International Trade Organization died an early death largely because protectionists in the United States and elsewhere feared it would not permit enough of a firewall between international and national economies. ${ }^{26}$ Debates about human rights exposed the STO's grounding in the bedrock of territorial sovereignty, as opposed to the universalist aspirations of the LIO. ${ }^{27}$ Even cultural rights are framed as belonging universally to individuals, not cultural groups per se. ${ }^{28}$ Group rights had roots in the STO but lacked a firm platform in the LIO, but universal human rights continue to struggle against the competing norm of territoriality. Tensions bubble to the surface in the area of rights of indigenous peoples, where universalizing concepts of nondiscrimination enjoy far greater consensus than a collective right to land. ${ }^{29}$

The central divergence, as we see it, is between liberalism's commitment to universalism, aggregate welfare, and individual utility on the one hand, and theories that assign power and meaning to locale, groups, and bordering on the other. Classical liberal theory does not have especially sharp tools for analyzing the latter. Some liberal thinkers have tried, but the struggle to

\footnotetext{
${ }^{26}$ Diebold 1952.

${ }^{27}$ The Universal Declaration of Human Rights universalizes individual rights in practically every one of its 30 articles, referring 30 times to "everyone" and eight times to "no one." Social groups are not given much status. For example, "the family" as a social unit seems to have protective status in Article 16(3). There is a vague reference to duties to "the community" in Article 29(1). It is not specified what these duties are. Only the Preamble (para. 8) refers to "peoples"- which in international law usually means identifiable ethnic or national groups. Importantly, however, peoples are themselves rights-holders.

${ }^{28}$ Universal Declaration of Human Rights, Articles 22 and 27(1).

${ }^{29}$ Lightfoot 2008:85-86. Kymlicka 1995 argues that liberal theory cannot readily justify indigenous rights. The Indigenous and Tribal Peoples' Convention (ILO C169, https://www.ilo.org/dyn/normlex/en/f?p=NORMLEXPUB:12100:0::NO::P12100_ILO_CODE:C169) contains cultural and territorial guaranties for indigenous peoples, but it has gleaned only 23 ratifications.
} 
make sense of space and place is evident in a simultaneous reading of Adam Smith's Theory of Moral Sentiments and The Wealth of Nations. In the former, Smith echoed the insights of David Hume $^{30}$ and others, asserting that real sympathy among human beings is largely spatial. Smith's theory of "habitual sympathy" was based on the centripetal pull of human proximity and familiarity, ${ }^{31}$ or "social distance" in Viner's terms. ${ }^{32}$ It is telling that his notion of spatially dependent sympathy led Smith to expect national "partiality," 33 which was one reason Smith held out very little hope for widespread compliance with "the laws of nations." 34 Acknowledging the social glue of local sentiment, Smith nonetheless thought international trade would help overcome "nationalism" and produce peace. ${ }^{35}$ Indeed, he viewed "sovereignty as the maintenance of well-being through the management of [economic] flows." 36 That the satisfaction of economic transactions could substitute for that of community is an idea that has been attractive in neoclassical and mainstream economics ever since.

Borders are not easily explained in liberal theory, either. Liberalism's unease with borders - essentially an exercise in distinction-drawing — stems from its central commitment to universality. The demos of democratic theory is in principle unbounded. ${ }^{37}$ Yet liberals recognize there is no demos without boundedness. Modern liberals such as Rawls assume a closed political system to be governed. ${ }^{38}$ As Walzer says, “...distributive justice presupposes a bounded world within which distributions take place: a group of people committed to dividing, exchanging, and sharing social goods, first of all among themselves." ${ }^{39}$ Presupposes is the right word: governance itself seems to require such bordering. Benhabib views the dilemma between universal principles and sovereign self-determination as resting at the heart of democratic theory itself. ${ }^{40}$ Critical

\footnotetext{
${ }^{30}$ As Hume 2006 put it, "Sympathy with persons remote from us is much fainter than that with persons near and contiguous." Please do not falsely correct capitalization in quotes.

${ }^{31}$ Smith 1759 [2002].

32 Viner 2015 [1972]:80.

${ }^{33}$ Smith 1759 [2002]:272.

${ }^{34}$ Smith 1759 [2002]:269.

${ }^{35}$ Smith 1759 [2002]:269-70. See the discussion in Hill 2010.

${ }^{36}$ See the discussion in Shapiro 2002:11.

${ }^{37}$ See the discussion in Abizadeh 2008.

${ }^{38}$ Rawls 1971:60-65, bis.

${ }^{39}$ Walzer 2008, chap. 1.

${ }^{40}$ Benhabib 2005:673.
} 
theorists go further, declaring that borders are "a source of embarrassment for liberals of all stripes." ${ }^{41}$ Holmes notes that liberalism is "wholly unable to draw territorial boundaries." 42

This deficiency in theory and practice is also evident when it comes to human mobility. Nineteenth-century liberals claimed an individual right to emigrate, since "it was wrong to treat man as a 'passive agent in the hands of authority'."43 Contemporary liberal theorists struggle over the right to exclude people who want to immigrate. On the one hand, Walzer defends border restrictions against migrants on the basis of preserving "communities of character" that give meaning to political life, ${ }^{44}$ while on the other hand Carens deploys Nozick, Rawls, and utilitarianism to argue that liberalism offers little justification for limiting migration. ${ }^{45}$ The liberal stance on immigration thus remains unreconciled. ${ }^{46}$

Liberalism's commitment to universality underlies its relative silence on bordering, group determination, and spatial attachments. Liberal trade theory largely ignores space and dissolves boundaries. Prior to the relatively recent behavioral economics trend, economic models stripped people of their psychologies, their social identities, and their locations. ${ }^{47}$ Liberal trade theory largely ignored another (less elegant) branch of economics, location theory, which links value with location relative to markets and not with the quality of inputs alone. ${ }^{48}$ Space mattered in such accounts. But liberal economics could not find a theoretically satisfying way to incorporate this observation into their models. ${ }^{49}$ Political economy has had a hard time with preferences that are space-specific. People and the land they worked were theorized first and foremost as factors of production. ${ }^{50}$ Their preferences were largely assumed to be a function of their individual, or their household's, assets and other endowments. ${ }^{51}$ Independent utility functions assured that economic man meant individual man. The sociotropic turn ${ }^{52}$ in research on trade preferences was harder to model but seemed to capture an essential truth: people care about the places where they

\footnotetext{
${ }^{41}$ Kymlicka 2001.

42 Holmes 1995:39-40; see also Dauvergne 1999.

43 Jennings 2011:7 (online pagination), quoting Constant 1822.

44 Walzer 2008:61; see also Miller 2005.

${ }^{45}$ Carens 1987; see also Cole 2000.

${ }^{46}$ On this tension, we agree with Goodman and Pepinsky's central thesis of a fundamental tension between migration and the LIO (this issue).

47 Davis 2013.

${ }^{48}$ See the discussion of Smith and Ricardo compared to von Thünen in Maier 2016:161-64.

49 Krugman 1993.

${ }^{50}$ Rogowski 1989.

${ }^{51}$ Scheve and Slaughter 2001.

${ }^{52}$ Mansfield and Mutz 2009.
} 
live; place fundamentally matters to economic behavior. The attachment to place, it turns out, can evoke strong urges to draw distinctions between Us and Them- that is, to border.

To summarize, there is a tension between liberal theory's emphasis on universality and the necessity in liberal democratic theory to distinguish and hence to bound a polity for purposes of self-governance. ${ }^{53} \mathrm{We}$ are not arguing against liberalism. We are arguing that the overlay of a liberal international order over a preexisting territorial one is a source of theoretical and practical tension that has created blind spots for policy, research, and scholarship. These blind spots are the product of intellectual commitments that privilege market integration, aggregate welfare, joint gains, universal rights, and methodological individualism. Far from coevolving in a natural, reciprocal, and irreversible manner, the STO and the LIO have managed to coexist through a series of negotiated agreements, from free trade to open borders to universal human rights, the political support for which has begun to shift in response to the hyperglobalization of the past three decades.

\section{Competing Pressures: The LIO and STO in Conflict}

As globalization has accelerated, many borders have been softened or erased. In response, new forms of bordering have emerged. We identify three types of responses which defend and reinforce local identities: a societal identity reaction; the creation of new border authority at levels above and below the state; and national, often symbolic forms of traditional border reinforcement.

\section{The Identity Reaction}

The territorial order was so well ingrained that when challenged by the universalizing, integrating, and aggregating pressures of the LIO, the principle of clearly bounded governance shaped the response. The STO relied on territorial borders, which in turn foster group and identity formation. ${ }^{54}$ When borders are weakened — by trade, foreign ownership, immigration, or even "foreign values"-privileged members may experience a sense of external threat. This can

\footnotetext{
${ }^{53} \mathrm{~A}$ well-established literature in democratic theory deals with this tension. See for example the debates reflected in Benhabib 2004; Cohen 1999; Mouffe 2000.

${ }^{54}$ Pelkmans 2006:215.
} 
prompt what we call an identity reaction: exclusionary identities emerge in other forms to effectively reclaim the group boundaries previously defined by geographic borders. Whereas individuals had previously coordinated on the border and the principle of exclusion by area, in an attempt to maintain the group individuals may recoordinate on type, for example cultural or ethnic attributes.

Scholars in several disciplines have examined the consequences of the weakening or erasure of borders in the last 30 years. Pelkmans studied how the partitioned village of Sarpy/Sarpi on the border of Turkey and Georgia responded to the fall of the Iron Curtain. The differences created by the closed border did not disappear once it reopened. "Instead, the former cold war border became more 'truly' a divide between Islam and Christianity, Georgians and Turks, and Asia and Europe." 55 The weakening of the border was quickly followed by the recreation of that border in a different form, maintaining local group membership. Cultural distinctions which were largely the result of the old border now set the boundaries of the group and define group membership. Similarly, when East and West Germany reunited, the former border was replaced by a new cultural border which distinguished and effectively maintained the same groups. The new cultural border contrasted East German "socialist" values of "egalitarianism, modesty, solidarity, social security and stability" 56 to "arrogant" West Germans, who ostensibly did not share those values. As Andrews notes, "Ironically, as the Berlin Wall came down, the inner wall - the wall which marked the psychological distance between eastern and western Germany - was for many strengthened." ${ }^{57}$ The erasure of internal European borders as a result of the Schengen Agreement continued this pattern. In the Netherlands, Germany, Spain, and Portugal, border populations have reproduced the erased border and deployed cultural referents which maintain and perpetuate the groups formed by the old international borders. ${ }^{58}$

Identity reactions deserve more study. Rationalist perspectives emphasize borders' power to coordinate group identity, governance privileges, and public (club) goods. When borders fade, other coordinating focal principles, such as cultural type - along race, language, or religious divisions, for example — can emerge to maintain the group and the benefits it brings. Often

\footnotetext{
${ }^{55}$ Ibid.

${ }^{56}$ Wiesenthal, quoted in Andrews 2003:118-19.

${ }^{57}$ Andrews 2003:112-13.

${ }^{58}$ de Fátima Amante 2013:39.
} 
cultural differentiations closely approximating the earlier state border may (re)gain political salience. ${ }^{59}$ Dissolution of the border threatens group cohesion and elicits new forms of group reinforcement. Because falsification by type is easier than falsification of group membership by area, and therefore requires a higher standard of monitoring, in an identity reaction, individuals may adopt starker norms of group identity than existed prior to the border's elision. ${ }^{60}$ For example, nationalist groups may threaten internationalists with exclusion, by voting out globalists and electing populist leaders. National in-group members might double down by tapping anti-immigrant sentiments or foreign trade suspicions to deter internationalist defection. ${ }^{61}$ To liberal scholars, the rise of international institutions and transnational networks may look like cooperation; but to local communities, in an ironic reversal of perspective, it may represent defection. $^{62}$

Permeable borders are especially susceptible to such dynamics. Increased mobility has resulted in social profiling to reduce real or perceived threats to dominant national groups. Muslims crossing the "open" border between the United States and Canada, for example, are increasingly identified by country of origin for special scrutiny - an intensified form of social differentiation that can increase identity formation by members of the profiled group. ${ }^{63}$ Around the highly porous Lesotho-South African Border, xenophobia has reinforced distinctions between insiders and outsiders, creating barriers to belonging in South Africa. ${ }^{64}$ Despite liberalized border trade between India and Pakistan, some studies suggest that "Indian Muslim citizens [have] consistently dealt with the stigma of 'the enemy within' and [have] had to prove their credentials as non-threatening citizens within the borders of India." ${ }^{65}$ While copious research documents a "liberal," or "democratic," peace, close spatial analysis shows that there may be a good deal of democratic "othering" associated with cross-border liberalization as well.

\section{State Reaction I: Squaring the Circle Through Multiplying Borders}

\footnotetext{
${ }^{59}$ Fearon 1999:17 presents a mechanism whereby weakening borders provides incentives for new exclusivist identities to form.

${ }^{60}$ Hardin 1995:74-75.

${ }^{61}$ Goodman 2014 discusses the role of "state identity" formation along these lines.

${ }^{62}$ See the contribution of DeVries, Hobolt, and Walter (this issue), arguing that politicized mass opinion can lead to "non-cooperative outcomes" at the international level.

${ }^{63}$ Nagra and Maurutto 2016; for similar research in the case of the United Kingdom see Mythen, Walklate, and Khan 2009.

${ }^{64}$ Kelly, Moletsane, and Coetzee 2017.

${ }^{65}$ Umar 2019:467.
} 
A second response to weakening borders may come from the state, which may be pressured to be "liberal" and "territorial" at the same time. States have incentives to create a bordering logroll that preserves public goods coordination while facilitating openness. Ad hoc arrangements for maintaining control are proliferating, from efforts to regulate the internet, to partially coordinated biometrics, to prescreening goods and travelers, to internal enforcement of immigration law. In a sense, borders now are everywhere. ${ }^{66}$ States deploy filters designed to be unobtrusive to the more internationalist membership, even as they develop border policies overtly designed to deter human movement. ${ }^{67}$ For example, airports present as shopping havens while obscuring securitization in an effort to provide affluent customers a pleasant experience. Increasingly, solutions to the problem of collective action are multiple, layered, and targeted.

The accretion of these solutions has produced a syncretic territorial state. Some new decision spaces entail solutions that explicitly reject state borders: Bitcoin, Doctors Without Borders, and "increasingly autonomous and private transnational structures, such as financial markets." ${ }^{68}$ In other cases, states are redefining their bordering authority and exerting it in a multitude of locations. Immigration control no longer occurs only at the border. After 9/11, for example, the United States authorized the DHS to "“assess the security risks of all US-bound travelers and prevent potential threats from reaching US borders'." ${ }^{69}$ What Amoore calls the "biometric" border can operate anywhere for purposes of control, exclusion, and proscription, essentially making a fixed border portable. ${ }^{70}$ Imports are no longer checked primarily at the border; preclearance licenses are often issued at the point of production. Some liberal societies now require private landlords to conduct immigration document checks on prospective tenants, essentially turning the private rental market into a border checkpoint. ${ }^{71}$

These are borders that even a liberal might tolerate, because they define belonging while facilitating movement for privileged transactions. But that may be precisely their weakness: multiple and moving borders are no longer clearly legible. ${ }^{72}$ The state is perhaps functionally intact, but it is symbolically weakened by manifold and mysterious structures of governance. ${ }^{73}$

\footnotetext{
${ }^{66}$ Wilson and Donnan 2016:19.

67 Martin 2012.

${ }^{68}$ Cerny 1995:620.

${ }^{69}$ Amoore 2006:337.

${ }^{70}$ Amoore 2006:338.

${ }^{71}$ McKee et al. 2020.

72 Brunet-Jailly 2012:103.

${ }^{73}$ Cerny 1995:596.
} 
Citizens can no longer apply to the syncretic state for redress or resolution. Now the authority to resolve their concerns is vested in an often bewildering array of vertically nonintegrated institutions, leading to "a growing disjunction between the democratic, constitutional, and social aspirations of people - which continue to be shaped by and understood through the framework of the territorial state - and the increasingly problematic potential for collective action through state political processes." 74 By attempting to situate the LIO on the foundations of a national territorialized order, shifting and disappearing borders may, in Hardin's framework, fail to assuage a nationalist coalition of groups who fear internationalist defection and want to return to an earlier notion of security and belonging, not obscure it with technology or delegate it in multiple directions. For these groups, it may be desirable for the state to provide structures and symbols of secure identity, rather than piecing together its authority willy-nilly.

\section{State Reaction II: Border Reinforcement}

Thus, even attempts to square the circle by erecting multiple, moving, and invisible borders may not suffice to address the anxieties of globalization. Instead, many states have doubled down on territoriality by erecting protective structures along their borders. One interpretation is that these policies are meant to legitimate the state's territorial authority, and to solidify a faltering sense of national identity and growing insecurity.

State-created walls and fences are unmistakably on the rise worldwide. ${ }^{75}$ Their intensification — decades after the height of the globalization of the 1980s and 1990s — suggests a plausible causal connection. Simmons and Kenwick have developed a concept of "border orientation," defined as the extent to which the State is committed to the public, authoritative, and spatial display of control over territorial entry and exit at its national borders. ${ }^{76}$ This definition captures the idea that (often symbolic) physical border structures are responses to challenges to state territorial authority. ${ }^{77}$ While autocratic states score higher on this measure and have accelerated border infrastructure faster than democracies, liberal regimes have accelerated physical border controls as well. Poland, Latvia, and Norway have all announced and built

\footnotetext{
${ }^{74}$ Cerny 1995:618.

${ }^{75}$ Carter and Poast 2015; Hassner and Wittenberg 2015; Vallet 2016.

${ }^{76}$ Simmons and Kenwick 2020.

${ }^{77}$ Brown 2010.
} 
border fences since 2015. The trend has gained momentum elsewhere in the Western Hemisphere. Argentina began to develop a series of small fences in 2015, ostensibly to control border-crossing traffic, and in 2017 Ecuador started building a wall on the Peruvian border to control smuggling. In 2015-16 an American presidential campaign, and in 2018 the longest governmental shutdown in US history, were centered on the contentious matter of walling the southern border of the United States. ${ }^{78}$

A growing physical presence at border crossings is especially intriguing. These are the spaces in which states, especially the non-Schengen wealthy democracies, tend to expend the most effort to filter, with structures and symbols that connect and separate, that facilitate and block exit and entry selectively. Satellite images reveal the increasingly dense built environment on each side of the world's international borders, visual evidence of the effort to filter persons, goods and services, and threats at the border crossing. In a sample of countries that include most of the liberal core, political leaders' populist rhetoric correlates with border orientation as well. ${ }^{79}$ Demands for territorial bordering are on the rise, even in this age of globalization.

International organizations have arguably contributed to the acceleration of border reinforcement in some cases. The European Union has long required border reinforcement along its outer edge as a key quid pro quo for joining the liberal Schengen interior. Even so, the migration crisis in Europe occasioned a number of national border controls in the ostensibly visafree Schengen zone. ${ }^{80}$ As borders become places of growing security anxiety, "secure borders" and "border measures" account for a growing share of business in the United Nations Security Council. ${ }^{81}$ But states rather than intergovernmental organizations (IGOs) are most often at the forefront of border restrictions. Recent anxieties surrounding the coronavirus have intensified the panic to make international borders "secure." Days after the World Health Organization (WHO) declared COVID-19 an international pandemic, 92 states had closed their land borders, 65 had closed their ports, and 109 had suspended international flights. ${ }^{82}$ Within a week of the WHO

\footnotetext{
${ }^{78}$ Secure Fence Act of 2006, Pub.L. 109-367 (signed into law October 26, 2006).

${ }^{79}$ Findings in this paragraph are from Simmons and Kenwick 2020.

${ }^{80}$ Fijnaut 2016.

${ }^{81}$ Simmons 2019, Fig. 6.

${ }^{82}$ As of March 24, 2020. Source: Aljazeera, "Coronavirus: Travel restrictions, border shutdowns by country," https:/www.aljazeera.com/news/2020/03/coronavirus-travel-restrictions-border-shutdowns-country200318091505922.html.
} 
determination, and though the WHO urged states not to do so, ${ }^{83}$ border closures in 58 states were nearly total. Many had doubled down on a narrative that the virus was a foreign threat that could effectively be blocked by sealing national borders against the Other.

\section{Empirical Agenda}

\section{International Organization's Liberal Lens}

$I O$ is both one of the most influential IR journals in the world, ${ }^{84}$ and has done more than any other to advance a liberal view of world politics. ${ }^{85} \mathrm{IO}$ 's widely cited special issues exemplify liberal projects, from transnational relations (1971), ${ }^{86}$ to international regimes (1982), ${ }^{87}$ to international legalization (2000), to the rational design of international institutions (2001). ${ }^{88}$ The common theme is that of states transcending territoriality through networks, cooperation, and international institutions. ${ }^{89}$ Interestingly, the version of constructivism favored in some of $I O$ 's key articles has focused on international elite socialization and identities; local identities that might resist sociological shifts were given less prominent analysis. ${ }^{90}$ This may explain why it was hard for scholars who read and publish in $I O$ to "anticipate the current challenges to the LIO"91: who was minding the growing opposition to the globalization of elite identities back home ${ }^{92}$

That liberalism is on the defensive and nationalism on the rise around the world is hardly news to anyone following politics, and is widely acknowledged in scholarly research in

\footnotetext{
${ }^{83}$ Euronews, "World Health Organization: Don't expect travel bans to beat coronavirus," March 13, 2020, https:/www.euronews.com/2020/03/13/world-health-organization-don-t-expect-travel-bans-to-beat-coronavirus; see also Bier 2020.

${ }^{84} \mathrm{IO}$ is consistently rated from first to third across hundreds of political science / IR journals, currently only behind the American Journal of Political science; see e.g. Scimago Journal \& Country Rank, https://www.scimagojr.com/journalrank.php?category $=3320$.

${ }^{85}$ Nielsen and Stewart (unpublished 2011 manuscript, on file with the author) find that $I O$ anchors the far liberal end of the theoretical spectrum, based on unique language associated with realist, liberal, and constructivist research paradigms published in major political science and IR journals between 1980 and 2006.

${ }^{86}$ Nye and Keohane 1971:331.

${ }^{87}$ Krasner 1983.

${ }^{88}$ Koremenos, Lipson, and Snidal 2001:763.

${ }^{89}$ A major theme in Ruggie 1993.

${ }^{90}$ Goldstein et al. 2000:393; Checkel 2005:815.

${ }^{91}$ Lake, Martin, and Risse, Introduction.

${ }^{92} I O$ has more recently published some important individual articles that feature analyses of space, borders and territory: Branch 2011; Zacher 2001; Carter and Goemans 2011; Shelef 2016; Goemans and Schultz 2016; for an insightful critique of globalization in the current context, see also Cerny 1995.
} 
geography, sociology, and comparative politics. John Ruggie's idea of embedded liberalism reminds us that domestic social purposes shape and constrain international cooperation and globalization. The understanding of such social purposes would benefit from a spatial analysis of identity and attitude formation, national policy agendas, and patterns of globalization. Research should build on insights from theories of social identity that view group membership as fundamental to identity. ${ }^{93}$ Group identity has a strong spatial component: distance attenuates attachments, while borders shape a sense of group membership by delineating ingroups and outgroups - the sociological complement to our argument about the need for spatially defined group coordination of public goods. We call for research on spatialized identities, and how these identities are coordinated by markers of community. This involves detailed attention to the scale of meaningful political activity, research into ways that scale can be muted and manipulated, and study of international and transnational institutional adaptations to recognize the value of clear international borders while acknowledging the threats they can create.

\section{Taking Spatial Preferences Seriously}

Globalization has not been experienced as a spatially homogeneous force. Trade shocks from Chinese exports tend to affect regions throughout the world with uncompetitive manufacturing sectors in decline; ${ }^{94}$ technological shocks have differently benefited regions where technological spillovers are greatest; ${ }^{95}$ a global coronavirus pandemic has hit urban centers especially hard. Local experiences and perceptions matter. ${ }^{96}$ We suggest a research agenda that examines the perceived need to alter, elide, and reinforce the boundaries of political space based on these experiences. Andrew Moravscik's analysis of "ideational liberalism"-a liberal account of politics which explains state preferences as shaped by social identities and values, which in turn are historically and spatially contingent—-suggests a liberal framework that recognizes the importance of place and borders for IR. ${ }^{97}$ He identifies geographical borders as one of three "essential elements of domestic public order," and generators of fundamental social dynamics that could in turn drive foreign policy behaviors of the state. Spatialized border politics

\footnotetext{
93 Tajfel 1981.

94 Autor, Dorn, and Hanson 2013.

95 Iammarino, Rodriguez-Pose, and Storper 2018.

96 Political attitudes are profoundly influenced by localized experiences (Egan and Mullin 2012).

${ }^{97}$ Moravcsik 1997.
} 
should be much more closely and deliberately integrated into the growing body of research on immigration, for example.

Globalization has neighborhood effects. These effects have potentially powerful influence on attitudes about inclusion and exclusion. Variation in urban ethnic composition has helped increase tolerance for different ethnic groups, ${ }^{98}$ a finding of potential interest for spatial preferences for stronger border control. Ryan Enos has recently proposed that perceptions leading to political action can be influenced by social geography: the size of a group, the proximity between groups, and the extent to which they mix with other groups. ${ }^{99}$ He proposes that when a distinctive group emerges in a nearby area, but is largely segregated from another group, backlash is predictable. ${ }^{100}$ These insights could be unpacked and applied to understand polarization over national border hardening, for example in the United States, Europe, India, and South Africa. Border control becomes a polarizing issue between communities with very different social geographies.

Spatial preferences and identities should not be confused with cultural preferences and identities. It would be a mistake to conflate attachment to the "nation" with attachment to the territory of the state. A series of survey experiments in Bolivia, Argentina, Colombia, and Thailand demonstrates the power of spatial identities. Respondents were asked about their willingness to sacrifice for the defense of the homeland, and their attitudes toward various attributes of national identity. ${ }^{101}$ Alongside these questions, half of the respondents were shown the outline of a map of their country. These respondents were willing to sacrifice significantly more for the defense of their homeland, compared to the ones who were not primed with the map. However, exposure to the map did not affect attitudes toward co-nationals or feelings of national attachment. These findings do not support the well-known argument by Anderson that maps can be and often are used to foster "national" identities. ${ }^{102}$ Instead, they reaffirm that coordination on borders does not necessarily align with coordination on type.

\footnotetext{
98 Kasara 2013.

${ }^{99}$ Enos 2017.

${ }^{100}$ Enos 2017:234.

${ }^{101}$ Goemans, Zhou, and Weintraub 2018. Joel Selway preregistered his parallel survey in Thailand at egap.org, under ID 20191217AD.

102 Anderson 1991.
} 
We therefore call for new research on spatial identities. Such research might consider how the "nation," the state, and communities at different scales compete to construct identities. It seems obvious that there often are important political and economic consequences when states redraw their internal administrative boundaries. But since Roeder showed that successful nationalist independence movements typically rely on administrative and not cultural boundaries to delimit their new independent states, we now need to understand how changes in administrative boundaries affect local identity formation. ${ }^{103}$ Gavrilis showed that institutions at the border can fundamentally affect interstate relations. ${ }^{104}$ We need additional studies to examine the effects of different forms of bordering. How do walls, fortifications, and biometric and other diffuse borders affect identity?

Taking spatial preferences seriously acknowledges that distinct spatial identities may exist and interact at different scales. As our reference to Adam Smith's Theory of Moral Sentiments suggests, liberals can acknowledge that distance erodes sentiments of commonality and trust. This insight should infuse analyses of the LIO. Research in social psychology has found that distance is correlated with objectification of others, less emotional intensity, and less sense of moral obligation. ${ }^{105}$ Perhaps global integration of markets and pooling of authority has stretched the idea of the polity beyond that which can be sustained (i.e., beyond its ability to effectively coordinate social purpose) without relentless efforts to reinforce a more expansive spatial identity. The European Union has faced this problem, ${ }^{106}$ as Brexit illustrates, but modern states are hardly immune to the perception that governance is not only unaccountable but increasingly distant. ${ }^{107}$ States as varied as the Soviet Union, Czechoslovakia, and Sudan have been challenged to hold together when local interests and identities clash and gain salience. If distance changes how people think about events, other people, and political authority, then the elision of borders can be expected to affect identity formation.

Political economy research has established that attitudes toward integrating moves such as international trade are not influenced by people's incomes and assets alone, but rather by

\footnotetext{
103 Roeder 2007.

104 Gavrilis 2008.

105 Amit and Greene 2012; Fujita et al. 2006; Williams and Bargh 2008.

${ }^{106}$ For an interesting account of EU efforts to forge a common identity through everyday symbols and practices, see McNamara 2015.

${ }^{107}$ Calhoun 1988.
} 
general attitudes toward citizens of other countries and even differential valuation of the lives of nationals versus foreigners. ${ }^{108}$ Research should continue to probe the spatial limits of neighborliness. Does it extend discontinuously over (bordered) space? ${ }^{109}$ What are the conditions under which survey respondents have discontinuous preferences across borders? We envision the use of geocoded surveys, and localized text analysis of news publications, social media, and other forms of political dialogue, to tap the sources of identities, preferences, and attitudes in space.

Finally, more research is needed on the consequences of doubling down on border security. We have argued it may assuage fears associated with a debordered world, but there may also be insidious consequences. Border security can be interpreted as a humiliation, as a recent survey of Palestinians traversing West Bank checkpoints has shown. ${ }^{110}$ Border walls and fences may worsen bilateral relations between countries and their citizens. Whether reinforcing distinctions in physical space antagonizes outsiders, thus inflaming bilateral relationships, is an important and policy-relevant area for future research.

\section{Aggregating Preferences into National Choices}

Preferences alone do not constitute national policies. Nor are they inevitable or immutable. We need much more research on how political leaders and institutions accommodate or resist the tensions between the LIO and the STO. Many liberal internationalists assume that border hardening went out with the fall of the Berlin Wall. They also often interpret structures at border crossings and new technologies at airports as effectively designed to make cross-border transactions easier. This is only partially true. We believe the question is not whether states are successfully blocking their borders, but rather whom and what are they attempting to filter, and why.

We also need a deeper understanding of how anxieties about globalization are aggregated at a national scale. Leaders may depend on specific kinds of political coalitions that can be

\footnotetext{
${ }^{108}$ See the research of Diana C. Mutz, discussed here (https://www.radcliffe.harvard.edu/event/2016-diana-c-mutzlecture) with regard to a lecture at the Radcliffe Institute for Advanced Study, Harvard University, "How much is one American worth? Public opinion toward globalization." But see also Fordham and Kleinberg 2012, who still see a prime place for material self-interest.

${ }^{109}$ As suggested by Mishra and Mishra 2010, and as asserted by Adam Smith 1759 [2002].

${ }^{110}$ Longo, Canetti, and Hite-Rubin 2014.
} 
consolidated and strengthened by privileging nationals while "othering" nonnationals and marginalized citizens. IR theorists have leaned very heavily on democratic institutions to explain international behavior. They have yet to investigate how domestic institutions, such as the US Senate, magnify or assuage sentiments in particular geographic spaces, and with what implications for participation in the LIO. Attention should also be drawn to the internal borders that (re)produce values of exclusion nationally and internationally. Skewing preference aggregation through gerrymandered electoral districts is another technique that may benefit powerful but declining interests and their perspectives on hardening the border, for example to immigration. In short, when we take geographic preferences seriously it becomes necessary to go beyond how democratic a polity is, and to consider how institutions (over)represent spatially clustered attitudes in the policy process.

Political leaders are central to the domestic politics of bordering. Leaders' manipulation of maps, information, and rhetoric becomes extremely important. Populist rhetoric may be associated with the reassertion of the territorial order vis-à-vis the LIO. Rodrik relates the rise of populism, on both the left and the right, to specific global economic shocks. Populists from the left are often concerned with combatting threats from trade and investment, while those on the right are often concerned with immigration and refugees. ${ }^{111}$ One conception of populism clearly distinguishes two homogeneous and antagonistic groups, a "corrupt elite" and a "pure people"concepts that are often racially and nationally exclusive. ${ }^{112}$ Another framing sees populism as emerging from fissures between "globalists" and "territorialists," which transect traditional leftright divides. ${ }^{113}$ Left or right, both varieties of populism are largely anti-establishment, anti-elite, and, crucially, anti-globalization. Politicians may opportunistically tap these currents by highlighting border security and exclusivity as a salve to (dis)affected groups. We hypothesize that both functional and symbolic border displays are increasingly attractive under these circumstances. ${ }^{114}$ How political entrepreneurs in the "core" liberal democracies manage these tensions could have a significant impact on the stability of the LIO.

\footnotetext{
111 Rodrik 2018.

112 Mudde 2017.

113 Maier 2016:4-5.

114 See e.g. Simmons and Kenwick 2020.
} 
We also welcome research that gives a hard kick to the tires of our analysis. Have the allegedly disappearing borders of the modern state in fact made national collective action harder? In the 1990s, IR theorists thought that the "residual" state was losing legitimacy because the scale of specialization under global forces would make it harder for states to provide collective goods. ${ }^{115}$ Class-based, geographically concentrated fears (of being "left behind" with massive fiscal burdens, low investment, and a host of cultural "others" depressing wages and demanding services) grow when global forces overtake national ones, in turn fueling demands for clearer borders to define who pays into and who benefits from collective effort.

\section{Conclusions}

The LIO is not a new order imposed on a blank slate. As proposed at the outset of this article, it is more like a new addition built onto an eighteenth-century house. While some might prefer to dwell in the new addition, even they must deal with the constraints imposed by the preexisting foundations. Similarly, individuals, states, and institutions cannot escape all the constraints of the STO and the structure it imposes. Many have tried. When the "transnational classes" can escape responsibility toward their fellow citizens by hiring foreign nationals, investing across the border, and avoiding taxation by hiding their assets in foreign institutions, we might conclude that borders as institutions have failed to supply national collective action. But this does not mean borders are obsolete. The territorial order has a built-in logic of coordination and group formation, and many national politicians still find it convenient to mobilize fearful groups around calls for economic barriers, anti-immigrant policies, and border walls. Such policies may respond to group demands for coordination (nationalism or sectionalism) when defection (internationalism) has become cheaper and easier for many. Notice how this formulation precisely reverses the language of cooperation and defection found in the liberal IR literature. While optimistically envisioned as eroding in the 1990s, borders have been largely repurposed as institutions of group cohesion and control. ${ }^{116}$

\footnotetext{
${ }^{115}$ Cerny 1995:598.

${ }^{116}$ Newman 2006.
} 
Can the LIO continue to thrive on the foundations of a national territorialized order? Or can the circle be squared through multilateralism? The answers are not obvious. "Border security" and even "border cooperation" have ambiguous and contentious meanings in the LIO. States have made border security a soft obligation in a handful of recent multilateral treaties, ${ }^{117}$ but for the most part, border policies are practiced unilaterally without much regard to the impact on neighbors. Co-bordering is something of a necessity, ${ }^{118}$ but in practice, cooperation in this area can be hegemonic and repressive. ${ }^{119}$ Emphatically, we are not arguing that the reaction to globalization will return us to the nationalist autarky of the 1930s. The evidence to date is mixed and nuanced. We see interesting possibilities for research into the strength of support for the LIO in the face of cues from political leaders and coalitions to retreat behind "secure" borders.

In the 1990s, it seemed that the "residual" nation-state had outlived its legitimacy; today the presumption of legitimate global institutions is under challenge. There are many contradictions between a territorial system and a liberal order which have not been resolved. There are undoubtedly new and promising theoretical avenues to explore, and we urge more empirical work to uncover a hitherto obscured world of space and spatiality in IR. It is in the hope of revealing this world from a novel perspective that we offer this essay.

\section{References}

Abbott, Andrew. 1995. Things of Boundaries. Social Research 62 (4):857-82.

Abizadeh, Arash. 2008. Democratic Theory and Border Coercion: No Right to Unilaterally Control Your Own Borders. Political Theory 36 (1):37-65.

Akerman, James R. 1995. The Structuring of Political Territory in Early Printed Atlases. Imago Mundi 47 (1):138-54.

Amit, Elinor, and Joshua D. Greene. 2012. You See, the Ends Don't Justify the Means: Visual Imagery and Moral Judgment. Psychological Science 23 (8):861-68.

\footnotetext{
${ }^{117}$ An obvious example is the most recent (2007) US National Security Strategy (https://www.whitehouse.gov/wpcontent/uploads/2017/12/NSS-Final-12-18-2017-0905.pdf, accessed July 12, 2018).

${ }^{118}$ Longo 2017; Gavrilis 2008.

${ }^{119}$ Casas-Cortes, Cobarrubias, and Pickles 2016.
} 
Amoore, Louise. 2006. Biometric Borders: Governing Mobilities in the War on Terror. Political Geography 25 (3):336-51.

Anderson, Benedict R.O. 1991. Imagined Communities: Reflections on the Origin and Spread of Nationalism. Rev. ed. Verso.

Andrews, Molly. 2003. Continuity and Discontinuity of East German Identity Following the Fall of the Berlin Wall: A Case Study. In Cultures of Political Transition: Memory, Identity and Voice, ed. Paul Gready, 107-26. Pluto Press.

Autor, David H., David Dorn, and Gordon H. Hanson. 2013. The China Syndrome: Local Labor Market Effects of Import Competition in the United States. American Economic Review 103 (6):2121-68.

Balibar, Étienne. 2004. We, the People of Europe? Reflections on Transnational Citizenship. Princeton University Press.

Barkin, J. Samuel, and Bruce Cronin. 1994. The State and the Nation: Changing Norms and the Rules of Sovereignty in International Relations. International Organization 48 (1):10730.

Benhabib, Seyla. 2004. The Rights of Others: Aliens, Residents, and Citizens. Cambridge University Press.

— 2005. Borders, Boundaries, and Citizenship. PS: Political Science \& Politics 38 (4):673-77.

Bier, David J. 2020. Research Provides No Basis for Pandemic Travel Bans. CATO Institute. https://www.cato.org/blog/research-provides-no-basis-pandemic-travel-bans.

Branch, Jordan. 2011. Mapping the Sovereign State: Technology, Authority, and Systemic Change. International Organization 65 (1):1-36.

- 2013. The Cartographic State: Maps, Territory, and the Origins of Sovereignty. Cambridge University Press.

Brantingham, P. Jeffrey, George E. Tita, Martin B. Short, and Shannon E. Reid. 2012. The Ecology of Gang Territorial Boundaries. Criminology 50 (3):851-85.

Brenner, Neil. 1998. Between Fixity and Motion: Accumulation, Territorial Organization and the Historical Geography of Spatial Scales. Environment and Planning D: Society and Space 16 (4):459-81.

Brown, Wendy. 2010. Walled States, Waning Sovereignty. Zone Books. 
Brunet-Jailly, Emmanuel. 2012. Securing Borders in Europe and North America. In $A$ Companion to Border Studies, eds. Thomas M. Wilson and Hastings Donnan, 100-18. John Wiley \& Sons.

Calhoun, Craig. 1988. Populist Politics, Communications Media and Large Scale Societal Integration. Sociological Theory 6 (2):219-41.

Carens, Joseph H. 1987. Aliens and Citizens: The Case for Open Borders. Review of Politics 49 (2):251-73.

Carter, David B., and H. E. Goemans. 2011. "The Making of the Territorial Order: New Borders and the Emergence of Interstate Conflict. International Organization. 65(2) (Spring 2011): $275-309$

Carter, David B., and Paul Poast. 2015. Why Do States Build Walls? Political Economy, Security, and Border Stability. Journal of Conflict Resolution 61 (2):239-70.

Casas-Cortes, Maribel, Sebastian Cobarrubias, and John Pickles. 2016. "Good Neighbours Make Good Fences": Seahorse Operations, Border Externalization and Extra-Territoriality. European Urban and Regional Studies 23 (3):231-51.

Cerny, Philip G. 1995. Globalization and the Changing Logic of Collective Action. International Organization 49 (4):595-625.

Checkel, Jeffrey T. 2005. International Institutions and Socialization in Europe: Introduction and Framework. International Organization 59 (4):801-26.

Cohen, Jean L. 1999. Changing Paradigms of Citizenship and the Exclusiveness of the Demos. International Sociology 14 (3):245-68.

Cole, Philip. 2000. Philosophies of Exclusion: Liberal Political Theory and Immigration. Edinburgh University Press.

Constant, Benjamin. 1822. Commentaire sur l'ouvrage de filangieri. P. Doufart Librarie. Dauvergne, Catherine. 1999. Amorality and Humanitarianism in Immigration Law. Osgoode Hall Law Journal 37 (3):597-624.

Davis, John B. 2013. The Theory of the Individual in Economics: Identity and Value. Routledge. de Fátima Amante, Maria. 2013. Recovering the Paradox of the Border: Identity and (Un)Familiarity across the Portuguese-Spanish Border. European Planning Studies 21 (1):24-41. 
Diebold, William Jr. 1952. The End of the ITO. Princeton Essays in International Finance, No. 16. Princeton, NJ: Princeton University.

Egan, Patrick J., and Megan Mullin. 2012. Turning Personal Experience into Political Attitudes: The Effect of Local Weather on Americans' Perceptions About Global Warming. Journal of Politics 74 (3):796-809.

El Ouali, Abdelhamid. 2006. Territorial Integrity: Rethinking the Territorial Sovereign Right of the Existence of the States. Geopolitics 11 (4):630-50.

Enos, Ryan D. 2017. The Space Between Us: Social Geography and Politics. Cambridge University Press.

Fearon, James D. 1999. What Is Identity (as We Now Use the Word)? Unpublished manuscript, Stanford University, Stanford, Calif. (http://www.web.stanford.edu/group/fearonresearch/cgi-bin/wordpress/wp-content/uploads/2013/10/What-is-Identity-as-we-nowuse-the-word-.pdf).

Fijnaut, Cyrille. 2016. The Refugee Crisis: The End of Schengen? In The Containment of Organised Crime and Terrorism, ed. Cyrille Fijnaut, 825-41. Brill Nijhoff.

Fordham, Benjamin O., and Katja B. Kleinberg. 2012. How Can Economic Interests Influence Support for Free Trade? International Organization 66 (2):311-28.

Fujita, Kentaro, Marlone D. Henderson, Juliana Eng, Yaacov Trope, and Nira Liberman. 2006. Spatial Distance and Mental Construal of Social Events. Psychological Science 17 (4):278-82.

Gavrilis, George. 2008. The Dynamics of Interstate Boundaries. Cambridge University Press. Gellner, Ernest. 1983. Nations and Nationalism. Cornell University Press.

Goemans, Hein E. 2006. Bounded Communities: Territorial Changes and International Conflict. In Territoriality and Conflict in an Era of Globalization, eds. Miles Kahler and Barbara F. Walter, 25-61. Cambridge University Press.

Goemans, Hein E and Kenneth A. Schultz. 2017. "Unequal Ground: Homelands and Conflict." December 2016. International Organization 70(1): 33-63.

Goemans, HeinE., Andi Zhou, and Michael Weintraub. 2018. Maps to Die For. Pre-registered at egap.org under ID 20191111AB. Available from the author.

Goettlich, Kerry. 2019. The Rise of Linear Borders in World Politics. European Journal of International Relations 25 (1):203-28. 
Goldstein, J., M. Kahler, R.O. Keohane, and A.M. Slaughter. 2000. Legalization and World Politics: Introduction. International Organization 54 (3):385-99.

Goodman, Sara Wallace. 2014. Immigration and Membership Politics in Western Europe. Cambridge University Press.

Gordon, Edward. 1984. Article 2 (4) in Historical Context. Yale Journal of International Law 10 (2):271-78.

Grimson, Alejandro. 2012. Nations, Nationalism and "Borderization" in the Southern Cone. In $A$ Companion to Border Studies, eds. Thomas M. Wilson and Hastings Donnan, 195-213. John Wiley \& Sons.

Hardin, Russell. 1995. Self-Interest, Group Identity. In Nationalism and Rationality, ed. Mark Galeotti, 14-42. Cambridge University Press.

Hassner, Ron E., and Jason Wittenberg. 2015. Barriers to Entry: Who Builds Fortified Boundaries and Why? International Security 40 (1):157-90.

Hill, Lisa. 2010. Adam Smith’s Cosmopolitanism: The Expanding Circles of Commercial Strangership. History of Political Thought 31 (3):449-73.

Holmes, Stephen. 1995. Passions and Constraint: On the Theory of Liberal Democracy. University of Chicago Press.

Hopewell, Kristen. 2016. Breaking the WTO: How Emerging Powers Disrupted the Neoliberal Project. Stanford University Press.

Hopgood, Stephen. 2013. The Endtimes of Human Rights. Cornell University Press.

Hume, David. 2006. An Enquiry Concerning the Principles of Morals. Oxford University Press. Iammarino, Simona, Andrés Rodriguez-Pose, and Michael Storper. 2018. Regional Inequality in Europe: Evidence, Theory and Policy Implications. Journal of Economic Geography 19 (2):273-98.

Jackson, Robert H. 1987. Quasi-States, Dual Regimes, and Neoclassical Theory: International Jurisprudence and the Third World. International Organization 41 (4):519-49.

Jennings, Jeremy. 2011. Early Nineteenth-Century Liberalism. The Oxford Handbook of the History of Political Philosophy, 331-47.

Kasara, Kimuli. 2013. Separate and Suspicious: Local Social and Political Context and Ethnic Tolerance in Kenya. Journal of Politics 75 (4):921-36. 
Kelly, Melissa, Malilimala Moletsane, and Jan K. Coetzee. 2017. Experiencing Boundaries: Basotho Migrant Perspectives on the Lesotho-South Africa Border. Przeglad Socjologii Jakosciowej 13 (1):92-110.

Koremenos, Barbara, Charles Lipson, and Duncan Snidal. 2001. The Rational Design of International Institutions. International Organization 55 (4):761-99.

Krasner, Stephen D. 1983. Structural Causes and Regime Consequences: Regimes as Intervening Variables. In International Regimes, ed. Stephen D. Krasner, 1-21. Cornell University Press.

Krugman, Paul R. 1993. On the Relationship Between Trade Theory and Location Theory. Review of International Economics 1 (2):110-22.

Kymlicka, Will. 1995. Multicultural Citizenship: A Liberal Theory of Minority Rights. Clarendon Press.

- 2001. Territorial Boundaries: A Liberal Egalitarian Perspective. In Boundaries and Justice: Diverse Ethical Perspectives, eds. David Miller and Sohail H. Hashmi, 249-75. Princeton University Press.

Lightfoot, Sheryl R. 2008. Indigenous Rights in International Politics: The Case of “Overcompliant” Liberal States. Alternatives 33 (1):83-104.

Longo, Matthew. 2017. The Politics of Borders: Sovereignty, Security, and the Citizen After 9/11. Cambridge University Press.

Longo, Matthew, Daphna Canetti, and Nancy Hite-Rubin. 2014. A Checkpoint Effect? Evidence from a Natural Experiment on Travel Restrictions in the West Bank. American Journal of Political Science 58 (4):1006-23.

Maier, Charles S. 2016. Once Within Borders: Territories of Power, Wealth, and Belonging Since 1500. Belknap Press of Harvard University Press.

Mansfield, Edward D., and Diana C. Mutz. 2009. Support for Free Trade: Self-Interest, Sociotropic Politics, and Out-Group Anxiety. International Organization 63 (3):425-57.

Martin, Lauren L. 2012. "Catch and Remove": Detention, Deterrence, and Discipline in US Noncitizen Family Detention Practice. Geopolitics 17 (2):312-34.

McKee, Kim, Sharon Leahy, Trudi Tokarczyk, and Joseph Crawford. 2020. Redrawing the Border Through the "Right to Rent": Exclusion, Discrimination and Hostility in the 
English Housing Market. Critical Social Policy, https://doi.org/10.1177/0261018319897043.

McNamara, Kathleen R. 2015. The Politics of Everyday Europe: Constructing Authority in the European Union. Oxford University Press.

McNamee, Lachlan, and Anna Zhang. 2019. Demographic Engineering and International Conflict: Evidence from China and the Former USSR. International Organization 73 (2):291-327.

Meyer, John W., John Boli, George M. Thomas, and Francisco O. Ramirez. 1997. World Society and the Nation-State. American Journal of Sociology 103 (1):144-81.

Miller, David. 2005. Immigration: The Case for Limits. In Contemporary Debates in Applied Ethics, eds. Andrew Cohen and Christopher Wellman, 363-75. Blackwell.

Mishra, Arul, and Himanshu Mishra. 2010. Border Bias: The Belief That State Borders Can Protect Against Disasters. Psychological Science 21 (11):1582-86.

Moravcsik, Andrew. 1997. Taking Preferences Seriously: A Liberal Theory of International Politics. International Organization 51 (4):513-53.

Mouffe, Chantal. 2000. The Democratic Paradox. Verso.

Mudde, Cas. 2017. An Ideational Approach. In The Oxford Handbook of Populism, eds. Cristóbal Rovira Kaltwasser, Paul Taggart, Paulina Ochoa Espejo, and Pierre Ostiguy, 27-47. Oxford University Press.

Mythen, Gabe, Sandra Walklate, and Fatima Khan. 2009. 'I'm a Muslim, but I'm Not a Terrorist": Victimization, Risky Identities and the Performance of Safety. British Journal of Criminology 49 (6):736-54.

Nagra, Baljt, and Paula Maurutto. 2016. Crossing Borders and Managing Racialized Identities: Experiences of Security and Surveillance Among Young Canadian Muslims. Canadian Journal of Sociology 41 (2):165-94.

Nail, Thomas. 2016. Theory of the Border. Oxford University Press.

Newman, David. 2006. The Lines That Continue to Separate Us: Borders in Our "Borderless" World. Progress in Human Geography 30 (2):143-61.

Nielsen, Richard, and Brandon Stewart. 2011. International Relations: In Its Own Words. Annual Meeting of the International Studies Association, Montreal, Canada. 
Nye, Joseph S., and Robert O. Keohane. 1971. Transnational Relations and World Politics: An Introduction. International Organization 25 (3):329-49.

Olsson, Ola, and Gustav Hansson. 2011. Country Size and the Rule of Law: Resuscitating Montesquieu. European Economic Review 55 (5):613-29.

Osiander, Andreas. 2001. Sovereignty, International Relations, and the Westphalian Myth. International Organization 55 (2):251-88.

Ostrom, Elinor. 2000. Collective Action and the Evolution of Social Norms. Journal of Economic Perspectives 14 (3):137-58.

Pelkmans, Mathijs. 2006. Defending the Border: Identity, Religion, and Modernity in the Republic of Georgia. Cornell University Press.

Rae, Heather. 2002. State Identities and the Homogenisation of Peoples. Cambridge University Press.

Rawls, John. 1971. A Theory of Justice. Harvard University Press.

Rodrik, Dani. 2018. Populism and the Economics of Globalization. Journal of International Business Policy 1 (1):12-33.

Roeder, Philip G. 2007. Where Nation-States Come From: Institutional Change in the Age of Nationalism. Princeton University Press.

Rogowski, Ronald. 1989. Commerce and Coalitions: How Trade Affects Domestic Political Alignments. Princeton University Press.

Ruggie, John Gerard. 1982. International Regimes, Transactions, and Change: Embedded Liberalism in the Postwar Economic Order. International Organization 36 (2):379-415.

- 1993. Territoriality and Beyond: Problematizing Modernity in International Relations. International Organization 47 (1):139-74.

Sack, Robert D. 1986. Human Territoriality: Its Theory and History. Cambridge University Press. Sahlins, Peter. 1989. Boundaries: The Making of France and Spain in the Pyrenees. University of California Press.

Schelling, Thomas C. 1960. The Strategy of Conflict. Harvard University Press.

Scheve, Kenneth F., and Matthew J. Slaughter. 2001. What Determines Individual Trade Policy Preferences? Journal of International Economics 54:267-92.

Shapiro, Michael J. 2002. Reading “Adam Smith”: Desire, History and Value. Rowman \& Littlefield. 
Shelef, Nadav. 2016. "Unequal Ground: Homelands and Conflict.” December 2016. International Organization 70(1): 33-63.

Simmons, Beth A. 2019. Border Rules. International Studies Review 21 (2):256-83.

Simmons, Beth A., and Michael Kenwick. 2020. Border Orientation in a Globalizing World: Concept and Measurement. University of Pennsylvania. https://papers.ssrn.com/sol3/papers.cfm?abstract_id $=3326773$.

Smith, Adam. 1759 [2002]. The Theory of Moral Sentiments. In Cambridge Texts in the History of Philosophy, ed. Knud Haakonssen. Cambridge University Press.

Tajfel, Henri. 1981. Human Groups and Social Categories: Studies in Social Psychology. Cambridge University Press.

Tajfel, Henri, and John C. Turner. 1979. An Integrative Theory of Intergroup Conflict. In Organizational Identity: A Reader, eds. Mary Jo Hatch and Majken Schultz, 56-65. Oxford University Press.

Umar, Sanober. 2019. Constructing the "Citizen Enemy": The Impact of the Enemy Property Act of 1968 on India's Muslims. Journal of Muslim Minority Affairs 39 (4):457-77.

Vallet, Élisabeth. 2016. Borders, Fences and Walls: State of Insecurity? Routledge.

Viner, Jacob. 2015 [1972]. The Role of Providence in the Social Order: An Essay in Intellectual History. Princeton University Press.

Walzer, Michael. 2008. Spheres of Justice: A Defense of Pluralism and Equality. Basic Books. Williams, Lawrence E., and John A. Bargh. 2008. Keeping One's Distance: The Influence of Spatial Distance Cues on Affect and Evaluation. Psychological Science 19 (3):302-08.

Wilson, Thomas M., and Hastings Donnan. 2016. A Companion to Border Studies. John Wiley \& Sons.

Zacher, Mark. 2001. The Territorial Integrity Norm: International Boundaries and the Use of Force. International Organization 55 (2):215-50.

Zürn, Michael. 2018. A Theory of Global Governance: Authority, Legitimacy, and Contestation. Oxford University Press. 